\title{
Sampling marine sediment
}

Rainer Gersonde ${ }^{1}$ and Marit-Solveig Seidenkrantz ${ }^{2}$

'Alfred-Wegener-Institute Helmholtz Centre for Polar and Marine Research, Bremerhaven, Germany; Rainer.Gersonde@awi.de ${ }^{2}$ Centre for Past Climate Studies, Department of Geoscience, Aarhus University, Denmark

\section{Recovered in ocean basins and marginal seas, marine sediments represent valuable archives to reconstruct global past climate and ocean variability as far back as the Mesozoic time period (150-170 million years). Here, we give a short overview on how to recover sediments from the ocean floor.}

A n important prerequisite for successful sample site selection and the decision for an appropriate drilling strategy or coring device is the acoustic pre-site survey in the target area. To generate high-resolution 3D images of the ocean floor, multi-beam sonar systems are used. Such a system can accurately map the topography of an area with a width of up to five and a half times the water depth below the ship's track. For sediment coring (to a total depth of $70 \mathrm{~m}$ ) sediment echo-sounding systems such as PARASOUND or sub-bottom profilers provide information on the sediment deposition pattern and can register the sedimentary layering as deep as $200 \mathrm{~m}$ below the sea floor (Fig. 1). At sites selected for deep drilling, additional single or multi-channel seismic surveys are required to generate information on the structure and nature of deep sediment (> $100 \mathrm{~m}$ depth) and to prevent the accidental drilling of sediment rich in explosive and polluting hydrocarbons.

\section{Drilling techniques}

The longest and oldest marine records are recovered in the frame of the Integrated Ocean Drilling Program (IODP, www.iodp. org). Within the IODP, launched in 2003, and its predecessors the Deep Sea Drilling Project (DSDP, 1968-1983) and the Ocean Drilling Program (ODP, 1985-2003), a total of more than 3,300 sites have been drilled in all ocean basins. The oldest sediments yet recovered from the ocean are from the West Pacific and were dated to ca. 170 million years (Lancelot et al. 1990). IODP operates the riser-less vessel JOIDES Resolution (JR) for sediment drilling for paleoclimate studies. Additional mission-specific platforms are required for drilling in environments that are not always accessible to the $J R$, such as the sea-ice covered Arctic Ocean and shallow water sites.

The current coring techniques utilized by IODP include:

- The Hydraulic Piston Corer (HPC) and the Advanced Piston Corer (APC), which are push type, non-rotating tools that produce well-preserved, well-oriented and continuous cores from unconsolidated sediment. This makes the recovered sediment cores most suitable for paleoceanographic studies

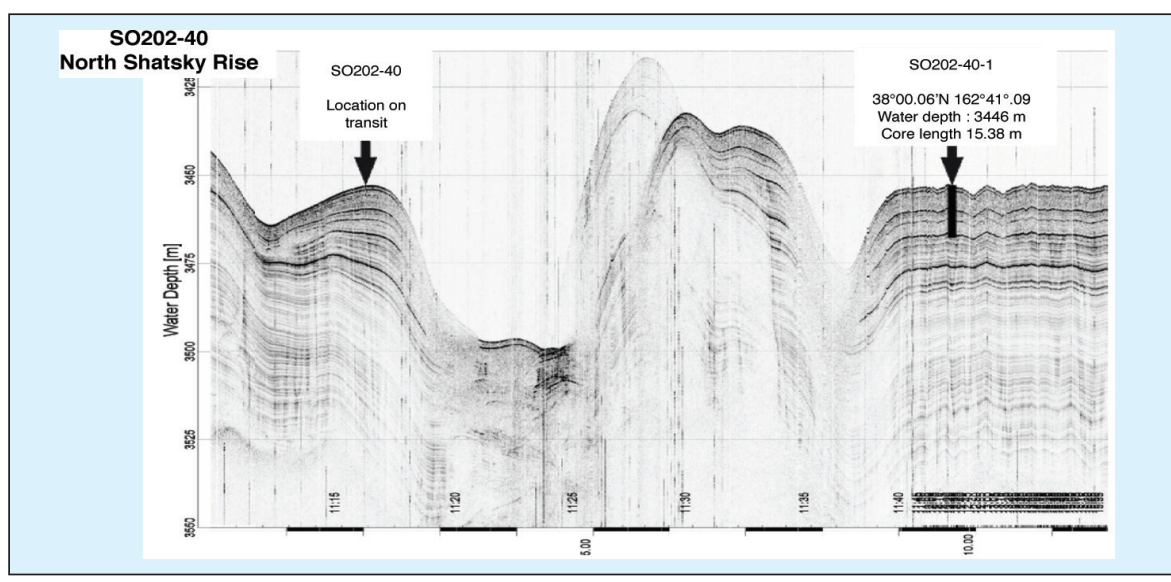

Figure 1: An example of a PARASOUND-survey at Site SO202-40 on the northern Shatsky Rise (from Gersonde 2012). PARASOUND penetration ranges around $75 \mathrm{~m}$. After selection of a sediment-coring site on a survey transit, the ship returned to the chosen location to recover a piston core. The 5-min-spaced time marks (lower panel) indicate that the ship was positioned at the site shortly after 11:40 am. The piston corer recovered the sediment as indicated by the black bar. After core recovery the ship remained at the site for further sampling.

at high resolution. The HPC/APC techniques, however, are generally limited to the upper $200 \mathrm{~m}$ of sediment.

- The Extended Core Barrel (XCB) coring system, which is used to recover deeper and more consolidated sediments.

- The Rotary Core Barrel (RCB) system, the oldest and most basic technique, which is used to retrieve cores from hard sediment and rock.

For all these techniques the sediment is retrieved in plastic liners. This allows the core, which is then cut into $1.5-\mathrm{m}$ segments, to be suitably handled, logged, and sampled on board and on shore. For a detailed compilation of IODP drilling techniques see http://www.iodp.org/iodp-drilling-a-coringtechnology.

Considering that access to drilling vessels is limited, MARUM (University of Bremen) has developed the MEBO sea floor drill rig (Freudenthal and Wefer 2007). MEBO weights 10 tons and can be deployed from standard research vessels. It is operable at water depths up to $2000 \mathrm{~m}$ and drills up to 80 -m-long cores. Thus, this relatively inexpensive drilling technique allows for the recovery of more consolidated sediment that cannot be collected with the available nondrilling methods (Box 1).

\section{Non-drilling techniques}

The paleoceanographic studies in the framework of the Past4Future project and similar research initiatives studying the late Pleistocene use cores drilled with the $J R$.
However, the main body of material is collected using non-drilling systems deployed from conventional research vessels. The basic design of the coring devices consists of one or more steel tubes or boxes attached below a lead weight unit. This set-up is winched to the sea floor and pushed into the sediment to recover a core. Below, we briefly review four main types of coring devices. Additional information and technical details on each device are given in Box 1 .

The simplest design is the gravity corer, consisting of an up to 20-m-long steel tube attached to a lead weight of 1-2 tons (Fig. 2A). Longer cores can, however, be recovered with the piston corer (Fig. 2B). Originally invented in 1947 by B. Kullenberg (Swedish Deep Sea Expedition) the piston corer has been further developed during the last few decades and is one of the most used coring devices within the marine coring community. Attached to the piston corer weight assembly is a trigger arm, which carries a wire with a small weight or a small gravity corer device (trigger corer) extending below the base of the piston corer tube. When the trigger corer penetrates the sea floor to collect the uppermost sediment sequence, the trigger arm is lifted and the piston corer is released falling freely with its own gravity into the sediment. When contact is made with the sediment surface, a piston, located inside the coring tube, is lifted up at the speed of penetration. Such a design reduces the friction inside the tube and allows for the collection of long cores. The Calypso 
Box 1: Comparison of three non-drilling techniques and one drilling technique

\begin{tabular}{|c|c|c|c|c|}
\hline & Gravity Corer & Piston Corer & Kasten Corer & MEBO sea floor drill rig \\
\hline Core diameter & $9-12 \mathrm{~cm}$ & $9-12 \mathrm{~cm}$ & $0.1 \times 0.1-0.3 \times 0.3 \mathrm{~m}^{2}$ & $7.4-8.4 \mathrm{~cm}$ \\
\hline Max. core length & up to $20 \mathrm{~m}$ & up to $60-70 \mathrm{~m}$ & $10-12 \mathrm{~m}$ & up to $80 \mathrm{~m}$ \\
\hline Total weight & $1-5$ tons & $1-10$ tons & $3-7$ tons & $\sim 10$ tons \\
\hline Max. water depth & Limited by ship wire length & Limited by ship wire length & Limited by ship wire length & $2000 \mathrm{~m}$ \\
\hline Advantages & $\begin{array}{l}\text { - Easy and fast handling } \\
\text { - Deployable in rough sea } \\
\text { - Core recovered in liner }\end{array}$ & $\begin{array}{l}\text { - Long core retrieval } \\
\text { - Core recovered in liner }\end{array}$ & $\begin{array}{l}\text { - Large volume of sediment } \\
\text { ideal for multi-proxy studies }\end{array}$ & $\begin{array}{l}\text { - Drills both soft and hard sediments } \\
\text { - Operates from standard research } \\
\text { vessels }\end{array}$ \\
\hline Drawbacks & $\begin{array}{l}\text { - Potential of over-penetration } \\
\text { (i.e. loss of the top sediment) } \\
\text { - Possible compression of } \\
\text { sediment and of non-uniform } \\
\text { recovery of deeper sediment } \\
\text { - Only works in soft sediment }\end{array}$ & $\begin{array}{l}\text { - Time consuming/complex } \\
\text { deployment } \\
\text { - Needs good sea conditions } \\
\text { - Potential sediment inflow } \\
\text { due to piston failure }\end{array}$ & $\begin{array}{l}\text { - Heavy core weight } \\
\text { - Needs good sea conditions } \\
\text { - Liner-less core recovery: } \\
\text { on-board sampling of core } \\
\text { - Only works in soft sediment }\end{array}$ & $\begin{array}{l}\text { - Time consuming/complex } \\
\text { deployment } \\
\text { - Needs good sea conditions } \\
\text { - Core recovery may be } \\
\text { discontinuous in sediment with } \\
\text { alternating composition } \\
\text { - High operation costs }\end{array}$ \\
\hline
\end{tabular}

piston corer operated from the French R/V (Research Vessel) Marion Dufresne and the US R/V Knorr can recover cores as long as 60 to $70 \mathrm{~m}$, depending on the type of sediments penetrated (for more details see http://perso-sdt.univ-brest.fr/ jacdev/uf08/ calypso.html and www.whoi.edu/page. do?pid=19095). Another simpler device is the kasten corer. This coring device also penetrates marine sediments by gravity and consists of long, rectangular boxes with up to 30 -cm-edge length (Fig. 2C). Because of the large volume of sediment sampled, this coring technique is beneficial for multiproxy paleoceanographic studies. Gersonde (2012) presents a photo gallery with the

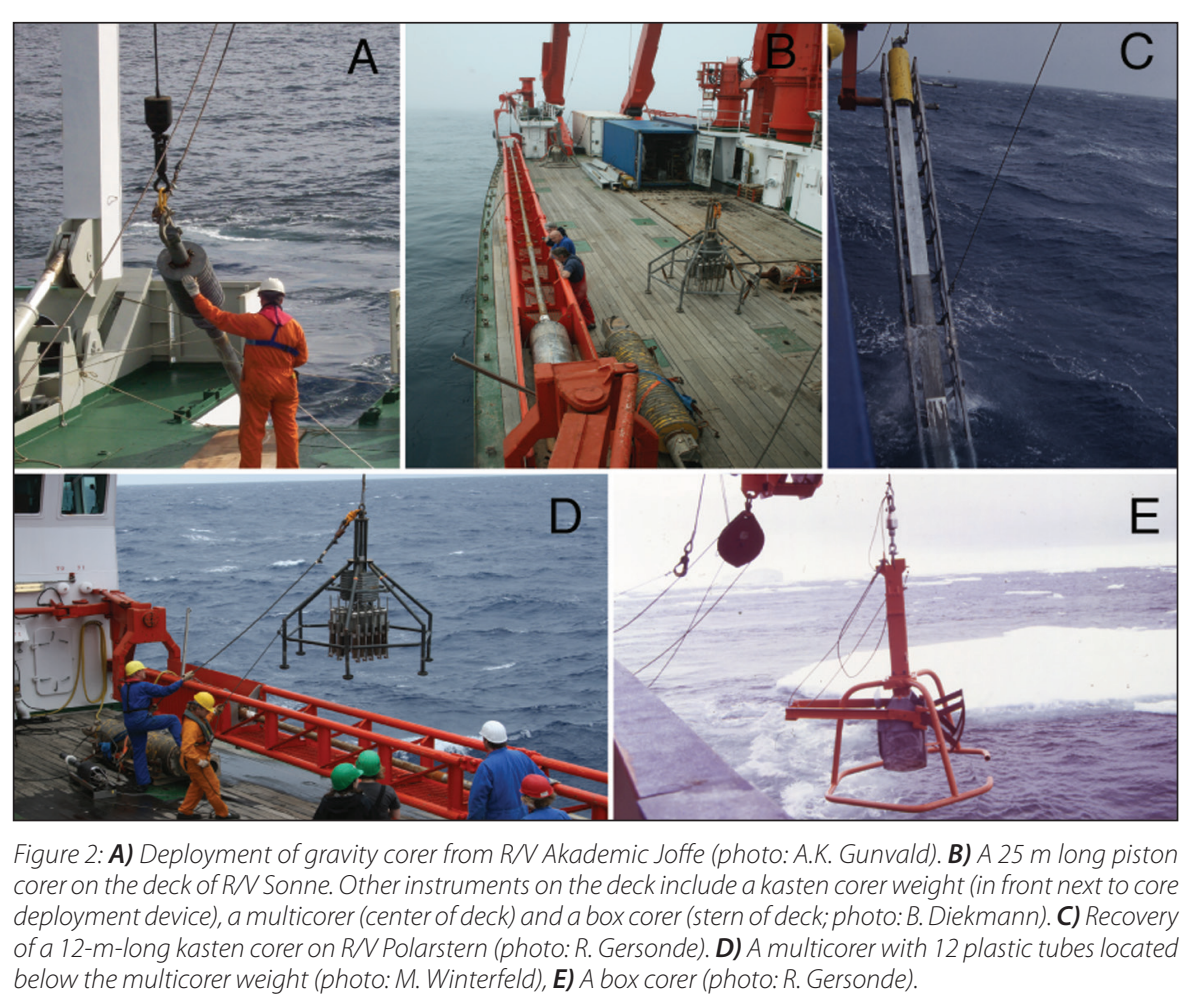

Figure 2: A) Deployment of gravity corer from RN Akademic Joffe (photo: A.K. Gunvald). B) A 25 m long piston corer on the deck of RN Sonne. Other instruments on the deck include a kasten corer weight (in front next to core deployment device), a multicorer (center of deck) and a box corer (stern of deck; photo: B. Diekmann). C) Recovery of a 12-m-long kasten corer on RN Polarstern (photo: R. Gersonde). D) A multicorer with 12 plastic tubes located below the multicorer weight (photo: M. Winterfeld), E) A box corer (photo: R. Gersonde).

set-up and handing of the different coring devices as well as on-board sampling.

Sediment coring is generally accompanied by surface sediment sampling for undisturbed recovery of the sediment/ water interface. This is most often achieved using a multicorer, which samples up to 12 individual cores (up to 50-cm-long; Fig. 2D). Surface sediment samples may also be obtained using different designs of grabs and box corers (Fig. 2E) but generally these do not result in the same quality of sampling as the multicorer. The surface sediment sampling is of importance for understanding modern sediment deposition and the development of reference data sets for paleoceanographic transfer functions. It also provides material for the reconstruction of the most recent ocean history.

\section{Marine sediment core storage}

National and international sediment core repositories assure long-term maintenance and curation of sediment materials under refrigerated conditions around $4^{\circ} \mathrm{C}$. Besides IODP core repositories located at College Station (US), Kochi (Japan) and Bremen (Germany), important repositories are at the Lamont-Doherty Earth Observatory (Columbia University), Scripps Institute of Oceanography, Florida State University (Talahassee), Oregon State University (Corvallis), Alfred Wegener Institute (Germany), MARUM (Bremen), and the British Ocean Sediment Core Research Facility.

Many countries (e.g. the US, Germany, France, Sweden, South Korea, Russia, Japan) operate research vessels that can deploy longer (more than $10 \mathrm{~m}$ ) coring systems. The ships are financed through international and national programs and may stay at sea for as long as 70 days per cruise. Long cruises are especially scheduled to visit remote areas, such as the polar oceans. Depending on the visited ocean basin and the cruise duration, the total recovery may exceed $1000 \mathrm{~m}$ of sediment core collected from up to 60 to 70 sites. Drilling cruises with the $J R$ last around 50 to 55 days and may recover more than $8000 \mathrm{~m}$ of sediment core during one single cruise.

\section{References}

Freudenthal T, Wefer G (2007) Scientific drilling with the sea floor drill rig MEBO, Scientific Drilling 5, doi: 10.22 04/iodp.sd.5.11.2007

Gersonde R (2012) Reports on Polar and Marine Research 643, doi: 10013/ epic.38996

Lancelot et al. (1990) Proceedings of the Ocean Drilling Program, Initial Reports 129, doi:10.2973/odp.proc.ir.129.1990 